\title{
A real life registry to evaluate patient profile, diagnostic and practice patterns in Acute Coronary Syndrome in Turkey: TURK-AKS study
}

\author{
Ömer Kozan ${ }^{\mathrm{a}, *}$, Oktay Ergene ${ }^{\mathrm{b}}$, Ali Oto ${ }^{\mathrm{c}}$, A. Keskin Kaplan ${ }^{\mathrm{d}}$, on behalf of the TURK-AKS Investigators \\ a Sağllk Bilimleri University, Siyami Ersek Hospital for Cardiology and Cardiovascular Surgery, Istanbul, Turkey \\ b Izmir Dokuz Eylul University, Faculty of Medicine, Izmir, Turkey \\ c Hacettepe University, Faculty of Medicine, Ankara, Turkey \\ ${ }^{\mathrm{d}}$ Turkish Foundation of Family Medicine, Istanbul, Turkey
}

\section{A R T I C L E I N F O}

\section{Article history:}

Received 14 February 2017

Received in revised form 20 August 2017

Accepted 22 August 2017

Available online 31 August 2017

\section{Keywords:}

Acute coronary syndrome

Patient profile

Practice patterns

STEMI

NSTEMI

Hospital admission

\begin{abstract}
A B S T R A C T
Background and objective: Evaluation of patient characteristics and the patterns of diagnostic therapeutic practices of acute coronary syndromes (ACS) in Turkey.

Methods: A total of 3695 ACS patients (mean age: $60 \pm 12$ years, $73 \%$ males) were included in this prospective, multicenter, non-interventional registry.

Results: ST-segment elevation and non-ST segment elevation myocardial infarction (NSTEMI) were identified in $57 \%$ and $43 \%$ of patients, respectively. In $65 \%$ of cases admission was directly to the index hospital. Ambulance transport was higher in rural sites comparing to urban areas ( 53.4 vs. $38.4 \%, \mathrm{p}<0.001)$.

Admission to a hospital within the first 2 h of symptom onset was $42 \%$ while after 12 h was $24 \%$. Spontaneous anginal relief (44\%) was the leading cause of late hospital admission. Fibrinolytic treatment was administered in $23 \%$ of the patients. The most common in-hospital interventions were coronary angiography for NSTEMI (18\%), primary percutaneous transluminal coronary angioplasty for STEMI (17.5\%) and coronary angiography after lytic therapy (12.1\%).

Conclusions: In a representative sampling for Turkish population five years ago, this registry of ACS revealed the predominancy of male gender, urban settlement, and presentation with STEMI. The delay between onset of symptoms and hospital admission was more prominent in rural sites, among females and in NSTEMI patients when compared to urban areas, males and STEMI patients.

(C) 2017 The Society of Cardiovascular Academy. Production and hosting by Elsevier B.V. This is an open access article under the CC BY-NC-ND license (http://creativecommons.org/licenses/by-nc-nd/4.0/).
\end{abstract}

Disclosure statement: The authors have no financial support or conflicts of interest to disclose.

\section{Introduction}

Acute coronary syndrome (ACS) represents a broader clinical spectrum ranging from unstable angina (UA) to non-ST segment elevation, as well as ST segment elevation, or even myocardial infarction (STEMI-NSTEMI) with heterogeneity in diagnosis, while treatments, and prognoses stand at the different ends of this spectrum. ${ }^{1-3}$ In this respect, aiming to reduce both the cardiovascular morbidity and mortality, as well as improving the quality of life; the current management of ACS is based on a combination of invasive revascularization strategies and pharmacologic treatments. According to current guidelines the

\footnotetext{
* Corresponding author at: Sağlık Bilimleri University, Siyami Ersek Hospital for Cardiology and Cardiovascular Surgery, Department of Cardiology, Haydarpașa, İstanbul, Turkey.

E-mail address: omer.kozan@deu.edu.tr (Ö. Kozan).

Peer review under responsibility of The Society of Cardiovascular Academy.
}

earlier the patient receives treatment, revascularization in specific, the greater the survival benefit with less damage via lesser likelihood of heart failure as a late outcome., ${ }^{4,5}$

In the frame of EUROASPIRE-European Action on Secondary and Primary Prevention by Intervention to Reduce Events I, II and III, the European Society of Cardiology (ESC) has carried out three consequent surveys on leading characteristics lifestyles, risk factor management and the drug therapies in patients with coronary heart disease (CHD). ${ }^{6-8}$ The comparison of the results between EUROASPIRE I and EUROASPIRE II with nine participating countries were examined, whereas the condition was described as a 'collective failure of medical practice'. Increasing adversive lifestyle trends, smoking, obesity, and no improvement in blood pressure management were noted as the contributing factors in these studies. ${ }^{9}$

Besides, On the other hand high incidence of atherosclerotic vascular diseases (5/100 person-years) in Turkey is notable despite the predominance of younger population as reported in TEKHARF, THS, TURDEP, PATENT and TURKSAHA studies, which further revealed substantial data on the association between risk factors and the increased incidence of ACS in Turkish population. ${ }^{10-16}$ 
However, there have been great progresses in the field of acute and chronic care of coronary heart diseases and evidence-based ACS treatment strategies, yet still a vast gap in clinical practice does exist. ${ }^{17}$

In addition, former registry studies on ACSs in Turkey were based mainly on localized data. Predominant inclusion of highly specialized cardiovascular centers was less likely to represent the ACS patient population in Turkey. The present national real-life registry was designed to evaluate current data on sociodemographic profile and presentation characteristics of patients as well as the diagnostic and practice patterns in the management of ACS across the country.

\section{Methods}

\section{Study population}

This large scale prospective, multicenter, observational registry study aimed to evaluate baseline sociodemographic and clinical characteristics of patients presenting with ACS (STEMI, NSTEMI, UA) while depicting the current management practices of ACS in Turkey.

Participating healthcare centers were selected by the Project Advisory Board of the study based on the number of hospital beds across the country in relation to the hospital type (university/state/private) and distribution of specialists (cardiology/internal medicine) in each geographical region. Accordingly, a total of 383 physicians located in 6 geographic regions enrolled patients between January 2007 and August 2010. Patients admitted to a hospital with a presumptive diagnosis of ACS and consented to participate in this study were included.

Written informed consents were collected from each subject following detailed explanations of the protocol of the study which was conducted in accordance with the ethical principles stated in the "Declaration of Helsinki" and approved by the ethics committee and the Ministry of Health.

\section{Data collection}

During the hospital stay, patient demographics, medical history, concomitant medical conditions, clinical and laboratory data including electrocardiography (ECG) evaluation, cardiac symptoms, levels of creatine kinase-MB (CK-MB), troponin, biochemical and hematological parameters on admission and follow-up evaluations were recorded. Duration from symptom onset to hospital admission, reasons for delayed admission; pharmacological interventions (including fibrinolytic therapy, aspirin, clopidogrel, heparins, ACEIs, ARBs, calcium channel blockers, beta-blockers, and statins) during hospitalization and at the time of hospital discharge; coronary angiography, percutaneous coronary intervention $(\mathrm{PCI})$, and coronary artery bypass grafting (CABG) were recorded for each patient.

\section{Statistical analysis}

Patient sampling method was based on geographic distribution of population variations and available beds for ACS patients on the basis of number of available intensive care units (ICU) and post ICU beds for ACS patients at each geographic region. Sampling stratifications were made to 6 geographical regions.

The patient sample size estimation was based on the number of ACS occurring each year since 1998 according to Ministry of Health of Turkey statistics as a "time-series analysis" for ACS including all discharged patients and deaths. Enrolling a minimum of 3650 patients across 6 geographic regions of Turkey was estimated to be sufficient to determine specific knowledge ratio of $5 \%$ based on a power of $80 \%$ at a type I error of 0.05 .

Statistical analysis was performed by Stata software package (version 10.0, Texas, USA). Data were summarized by using descriptive statistics (mean, standard deviation, ratio, 95\% confidence interval where appropriate). Since this was a non-interventional trial, only available data were included in the analysis; however, number of missing data is not mentioned unless it is higher than $10 \%$ of the patients. Chi-square test was used comparisons of categorical data and $t$-test for continuous variables. All tests were two-sided and $\mathrm{p}<0.05$ was considered as statistically significant.

\section{Results}

A total of 3695 (mean age: $60 \pm 12$ years, $73 \%$ males) patients were included in the study. Females were significantly older (mean age $59 \pm$ 12 years for males and $67 \pm 11$ years for females; $\mathrm{p}<0.001$ ). Settlement was predominantly urban (77\%). The Body Mass Index was $27.5 \pm$ $4.09 \mathrm{~kg} / \mathrm{m}^{2}$ while mean height, weight and waist circumference were $171 \pm 6 \mathrm{~cm}(\mathrm{n}=1704), 79 \pm 12 \mathrm{~kg}(\mathrm{n}=1772)$ and $100 \pm$ $13 \mathrm{~cm}(\mathrm{n}=638)$ in males; and $159 \pm 6 \mathrm{~cm}(\mathrm{n}=489), 74 \pm 13 \mathrm{~kg}$ $(\mathrm{n}=528)$ and $102 \pm 15 \mathrm{~cm}(\mathrm{n}=226)$ in females, respectively. Waist circumference was $\geq 88 \mathrm{~cm}$ in $83 \%$ of females.

High blood pressure at hospital presentation (SBP $\geq 140 \mathrm{~mm} \mathrm{Hg}$ and $\mathrm{DBP} \geq 90 \mathrm{~mm} \mathrm{Hg}$ ) was identified in $23 \%$ of the overall population and more commonly among females ( 26 vs. $22 \%$, p < 0.001 ). Baseline demographics are presented in Table 1. Current smokers composed 69\% of the study population. Family history of coronary artery disease was evident in 34\%; and hypertension was the most common concomitant disease (48\%) (Table 1).

\section{Hospital admission}

In $65 \%$ of cases admission was directly to the index hospital. As expected, referred cases were more prevalent in rural areas when compared to urban settlement ( $50 \%$ vs 30\%, p < 0.001 ). Referral from the index hospital to another hospital was also more prevalent in rural areas ( 16 vs. $12 \%, \mathrm{p}<0.01$ ) Transportation by an ambulance was more frequent for patients living in rural areas (53 vs. 38\%, p < 0.001) (Table 2). Requirement for an invasive intervention was the most common reason (83.7\%) for referral to another hospital (Table 2).

Chest pain (93\%) was the most commonly identified symptom at hospital admission. The presentation of patients was STEMI in 57\% (mean age: $59 \pm 10$ years) and NSTEMI in 43\% (mean age: $63 \pm$

Table 1

Vital signs and medical history at hospital admission.

\begin{tabular}{llll}
\hline & Male & Female & Overall \\
\hline Vital signs & Mean $( \pm \mathrm{SD})$ & & \\
$\quad$ Systolic blood pressure $(\mathrm{mm} \mathrm{Hg})$ & 129.3 & 134.9 & 130.8 \\
& $(25.5)$ & $(28.1)^{* *}$ & $(26.3)$ \\
Diastolic blood pressure $(\mathrm{mm} \mathrm{Hg})$ & $78.3(14.9)$ & $78.8(16.4)$ & $78.4(15.3)$ \\
Pulse (beat/min) & $79.5(16.8)$ & $82.5(17.4)^{* *}$ & $80.3(17.0)$ \\
SBP $\geq 140$ and DBP $\geq 90 \mathrm{~mm} \mathrm{Hg}$ & $\mathrm{n}(\%)$ & & \\
& $555(21.6)$ & $236(25.6)^{*}$ & $791(22.6)$ \\
Smoking status & & & \\
Ex-smoker & $621(30.9)$ & $59(38.3)$ & $680(31.4)$ \\
Current smoker & $1388(69.1)$ & $95(61.7)$ & $1483(68.6)$ \\
Total & $2009(73.9)$ & $154(15.8)^{* *}$ & $2163(58.5)$ \\
Family history of coronary disease & $923(34.0)$ & $321(32.8)$ & $1244(33.7)$ \\
Concomitant diseases & & & \\
Hypertension & $1080(39.8)$ & $677(69.2)^{* *}$ & $1757(47.6)$ \\
Hyperlipidemia & $781(28.7)$ & $377(38.6)^{* *}$ & $1158(31.3)$ \\
Diabetes mellitus & $549(20.2)$ & $384(39.3)^{* *}$ & $933(25.3)$ \\
Past history of & & & \\
Myocardial infarction & $550(20.2)$ & $164(16.8)^{*}$ & $714(19.3)$ \\
Heart failure & $321(11.8)$ & $166(17.0)^{* *}$ & $487(13.2)$ \\
Transient ischemic attack & $67(2.5)$ & $41(4.2)^{*}$ & $108(2.9)$ \\
Stroke & $92(3.4)$ & $56(5.7)^{*}$ & $148(4.0)$ \\
Peripheral artery disease & $64(2.4)$ & $14(1.4)$ & $78(2.1)$ \\
Coronary artery bypass graft & $175(6.4)$ & $45(4.6)$ & $220(6.0)$ \\
Percutaneous coronary & $323(11.9)$ & $89(9.1)$ & $412(11.2)$ \\
intervention & & & \\
Stable angina pectoris & $680(25.0)$ & $300(30.7)^{* *}$ & $980(26.5)$ \\
\hline
\end{tabular}

* $\mathrm{p}<0.01$; compared to males.

** $\mathrm{p}<0.001$; compared to males. 
Table 2

Hospital admission in ACS patients with respect to location of residence.

\begin{tabular}{|c|c|c|c|}
\hline & \multicolumn{2}{|c|}{ Location of residence } & \multirow[t]{2}{*}{ Overall } \\
\hline & $\begin{array}{l}\text { Urban } \\
(\mathrm{n}=2802)\end{array}$ & $\begin{array}{l}\text { Rural } \\
(\mathrm{n}=858)\end{array}$ & \\
\hline Admission type & $\mathrm{n}(\%)$ & & \\
\hline Referred & $854(30.5)$ & $430(50.1)^{* *}$ & $1.293(35.0)$ \\
\hline Direct & $1.948(69.5)$ & $428(49.9)^{* *}$ & $2.402(65.0)$ \\
\hline \multicolumn{4}{|l|}{ Transport vehicle } \\
\hline Ambulance & $867(38.4)$ & $386(53.4)^{* *}$ & $1.261(42.1)$ \\
\hline Private transportation & $1.389(61.6)$ & $337(46.6)^{* *}$ & $1.736(57.9)$ \\
\hline \multicolumn{4}{|l|}{ Referral to another hospital } \\
\hline Overall & $330(11.8)$ & $142(15.9)^{*}$ & $472(12.8)$ \\
\hline \multicolumn{4}{|l|}{ Reason for referral } \\
\hline Cardiogenic shock & $10(3.0)$ & $3(2.1)$ & $13(2.8)$ \\
\hline Invasive intervention & $285(86.4)$ & $110(77.5)$ & $395(83.7)$ \\
\hline Pericarditis & - & $2(1.4)$ & $2(0.4)$ \\
\hline Cerebrovascular accident & - & $1(0.7)$ & $1(0.2)$ \\
\hline Conduction disorders $^{\mathrm{a}}$ & $8(2.4)$ & $7(4.9)$ & $15(3.3)$ \\
\hline Post-myocardial infarction angina & $15(4.6)$ & $11(7.8)$ & $26(5.5)$ \\
\hline Other & $42(12.7)$ & $13(9.2)$ & $55(11.7)$ \\
\hline
\end{tabular}

a Includes ventricular tachycardia/fibrillation, atrioventricular block, rhythm disorder and atrial fibrillation.

* $\mathrm{p}<0.01$; compared to urban location.

** $\mathrm{p}<0.001$; compared to urban location.

11 years) of the patients. Half of the patients were in New York Heart Association Class I (59\%) and Canadian Cardiovascular Society Class II (55\%); most of them were in sinus rhythm (96\%) and Killip status was Class I (82\%) (Table 3).

Mean duration of symptoms was $136( \pm 503)$ min in the overall population and there was no significant difference with respect to gender, settlement (Table 4) and the diagnosis (mean 152 (508) min in STEMI vs. 115 (496) min in NSTEMI.
Data concerning the duration between symptom onset and hospital admission in the overall population with respect to gender, settlement location and the diagnosis are summarized in Fig. 1. Figs. 2 and 3 show the detailed evaluation of the delay in hospital admission. The major reason for the delay in hospital admission was waiting for spontaneous relief (45\%) (Table 4).

\section{Hospitalization}

Time from hospital admission to hospitalization was found to be mean $2.0 \pm 5 \mathrm{~h}$. Majority of the patients were hospitalized to the coronary intensive care unit (ICU) (98\%) with a mean length of overall hospitalization for $5 \pm 3$ days (Table 5). In-hospital mortality was 3\% (107 cases) in the overall population. In-hospital mortality within the first $24 \mathrm{~h}$ was significantly higher in STEMI patients (42 vs. $21 \%, \mathrm{p}<0.05$ ) while mortality after $24 \mathrm{~h}$ was more common among NSTEMI patients ( 79 vs. $58 \%, \mathrm{p}<0.05$ ) (Table 5). Sudden cardiac death/ventricular fibrillation (VF) (32\%) and heart failure (30\%) were the most common reasons for in-hospital mortality (Table 5). Change in levels of CK-MB and troponin $\mathrm{I} / \mathrm{T}$ during hospital stay are shown in Table 6.

Fibrinolytic treatment, primary $\mathrm{PCI}$ and rescue $\mathrm{PCI}$ were all determined to be performed more frequently in earlier hospital admissions (Fig. 4). Overall 39.3\% ( $\mathrm{n}=826)$ of STEMI patients and 3.5\% $(\mathrm{n}=55)$ of NSTEMI patients received in-hospital fibrinolytic therapy (Table 7). Coronary angiography was performed in $18 \%$ of NSTEMI patients, $12.1 \%$ of post-lytic patients and primary PCI in $17.5 \%$ of STEMI patients (Table 7).

Representing the first large scale attempt to describe the patient profile, presentation characteristics and the diagnostic and practice patterns in ACS across Turkey, the present national registry revealed predominancy of male gender (73.5\%), age of 51 to 70 years (55.4\%), urban location (76.6\%) and STEMI (56.9\%) among ACS patients.

Besides, females were associated with older age, higher incidence of concomitant diseases and the increased likelihood of NSTEMI diagnosis

Table 3

Symptoms and cardiological status at hospital admission.

\begin{tabular}{|c|c|c|c|}
\hline & Male $(\mathrm{n}=2717)$ & Female $(\mathrm{n}=978)$ & Overall \\
\hline Symptoms at hospital admission & $\mathrm{n}(\%)$ & & \\
\hline Chest pain (angina) & $2560(94.2)$ & $911(93.2)$ & $3471(93.4)$ \\
\hline Dyspnea & $546(20.1)$ & $263(26.9)$ & 809 (21.9) \\
\hline Syncope & $87(3.2)$ & $45(4.6)$ & $132(3.6)$ \\
\hline Sweating & $914(33.6)$ & $280(28.6)$ & $1194(32.3)$ \\
\hline Palpitation & $271(10.0)$ & $160(16.4)$ & $431(11.7)$ \\
\hline Nausea/vomiting & $514(18.9)$ & $229(23.4)$ & $743(20.1)$ \\
\hline At admission or in-hospital sudden death & $14(0.5)$ & $2(0.2)$ & $16(0.4)$ \\
\hline Other & $235(8.7)$ & $106(10.8)$ & $341(9.2)$ \\
\hline \multicolumn{4}{|l|}{ Type of ACS } \\
\hline STEMI & $1656(61.0)$ & $446(45.6)$ & $2102(56.9)$ \\
\hline NSTEMI & $1061(39.1)$ & $532(54.4)$ & $1593(43.1)$ \\
\hline \multicolumn{4}{|l|}{ Rhythm disorder } \\
\hline Sinus rhythm & $2613(96.2)$ & $904(92.4)$ & $3517(95.2)$ \\
\hline Atrial fibrillation & $68(2.5)$ & $60(6.1)$ & $128(3.5)$ \\
\hline Other & $70(2.6)$ & $37(3.8)$ & $107(2.9)$ \\
\hline \multicolumn{4}{|l|}{ New York Heart Association class } \\
\hline 1 & $203(63.2)$ & $86(51.8)$ & $289(59.3)$ \\
\hline 2 & $84(26.2)$ & $54(32.5)$ & $138(28.3)$ \\
\hline 3 & $31(9.7)$ & $25(15.1)$ & $56(11.5)$ \\
\hline 4 & $3(0.9)$ & $1(0.6)$ & $4(0.8)$ \\
\hline \multicolumn{4}{|l|}{ Canadian Cardiovascular Society class } \\
\hline I & $204(30.0)$ & $78(26.0)$ & $282(28.8)$ \\
\hline II & $372(54.7)$ & $168(56.0)$ & $540(55.1)$ \\
\hline III & $79(11.6)$ & $49(16.3)$ & $128(13.1)$ \\
\hline IV & $25(3.7)$ & $5(1.7)$ & $30(3.1)$ \\
\hline \multicolumn{4}{|l|}{ Killip status } \\
\hline I & $1.529(84.3)$ & $472(75.0)$ & $2.001(81.9)$ \\
\hline II & $202(11.1)$ & $120(19.1)$ & $322(13.2)$ \\
\hline III & $63(3.5)$ & $30(4.8)$ & $93(3.8)$ \\
\hline IV & $20(1.1)$ & $7(1.1)$ & $27(1.1)$ \\
\hline Unknown & 903 & 349 & 1.252 \\
\hline
\end{tabular}


Table 4

Duration of symptoms and reasons for the delay in hospital admission.

\begin{tabular}{|c|c|c|c|c|c|c|}
\hline & & \multirow[t]{2}{*}{ Overall } & \multicolumn{2}{|l|}{ Location of residence } & \multicolumn{2}{|l|}{ Gender } \\
\hline & & & Urban $(\mathrm{n}=2802)$ & Rural $(\mathrm{n}=858)$ & Female $(\mathrm{n}=978)$ & Male $(\mathrm{n}=2717)$ \\
\hline Duration of symptoms (min) & Mean (SD) & $\begin{array}{l}136.0(503) \\
\mathrm{n}(\%)\end{array}$ & $136.7(557)$ & $136.9(279)$ & $153.5(675)$ & $129.6(423)$ \\
\hline Waiting for spontaneous relief & & $563(44.7)$ & $410(45.9)$ & $147(41.1)$ & $185(47.6)$ & $378(43.6)$ \\
\hline Ignored & & $186(14.8)$ & $136(15.2)$ & $48(13.4)$ & $47(12.1)$ & $139(16.0)$ \\
\hline Transport difficulties & & $141(11.2)$ & $61(6.8)$ & $80(22.4)$ & $48(12.3)$ & $93(10.7)$ \\
\hline It was thought to be gastric pain & & $133(10.6)$ & $105(11.8)$ & $27(7.5)$ & $34(8.7)$ & $99(11.4)$ \\
\hline It was thought to be muscle pain & & $94(7.5)$ & $80(9.0)$ & $14(3.9)$ & $37(9.5)$ & $57(6.6)$ \\
\hline Low socioeconomic status & & $78(6.2)$ & $36(4.0)$ & $42(11.7)$ & $32(8.2)$ & $46(5.3)$ \\
\hline Living alone & & $37(2.9)$ & $20(2.2)$ & $16(4.5)$ & $20(5.1)$ & $17(2.0)$ \\
\hline Other & & $111(8.8)$ & $72(8.1)$ & $38(10.6)$ & $38(9.8)$ & $73(8.4)$ \\
\hline
\end{tabular}

compared to males. The delay between onset of symptoms and hospital admission was more prominent in rural locations, among females and in NSTEMI patients when compared to urban location, males and STEMI patients.

In this respect, patient profile determined in our national registry is in line with the results of EUROASPIRE III $^{8}$ concerning the lifestyle, risk factors and use of cardioprotective drug therapies in coronary patients from 22 European countries which indicates the population sample to include $27.4 \%$ (3821) women with overall the mean (SD) age of $61.9^{10}$ years as well as results of the Turkey arm of EUROASPIRE III survey ${ }^{16}$ that indicated $23.8 \%$ of the population was composed to females. Likewise our finding of $21.1 \%$ of the study population was composed of patients that were younger than 50 years of age seems compatible with the higher rates of young patients with $\mathrm{MI}(<50$ years, $20 \% \mathrm{vs} .12 .7 \%)$ reported in Turkey arm of EUROASPIRE III study ${ }^{16}$ as well as the consistently reported unexpectedly high incidence of atherosclerotic vascular diseases $(5 / 100 \text { person-years })^{10}$ in Turkey in TEKHARF, ${ }^{11}$ THS, ${ }^{12}$ TURDEP, ${ }^{13}$ PATENT $^{14}$ and TURKSAHA ${ }^{15}$ studies despite having much younger population than in other European countries. ${ }^{16}$

Indeed, the most important differences specific to Turkey compared to other countries included in EUROASPIRE III study were reported to be higher rates of young patients with MI ( $<50$ years, $20 \%$ vs. $12.7 \%)$, persistence in smoking ( $23.1 \%$ vs. $17.2 \%)$, immobility, low HDL-cholesterol (50.2\% vs. $36.7 \%$ ), insufficient follow-up by physicians after the index

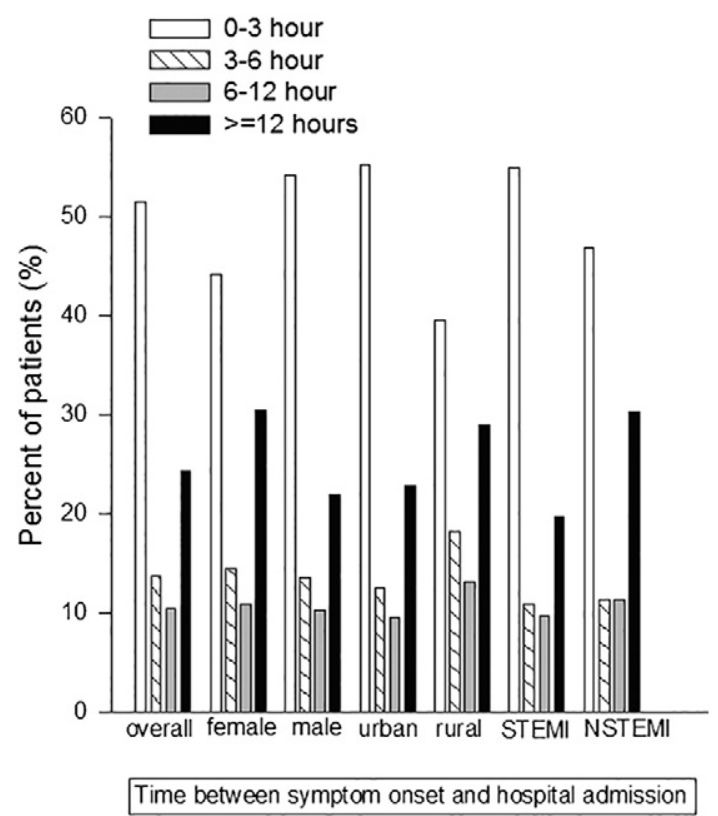

Fig. 1. Time between symptom onset and hospital admission in the overall population with respect to, gender, location of residence and the diagnosis. event (12\% vs. $2.2 \%$-except Turkey), and the insufficient patient education. $^{16}$

According to our findings, female gender seems to associate with older age (66.6 vs. 58.9 years), higher incidence of concomitant diseases including hypertension ( 69.2 vs. $39.8 \%$ ), hyperlipidemia ( 38.6 vs. $28.7 \%$ ) and diabetes mellitus (39.3 vs. $20.2 \%$ ) as well as increased diagnosis of NSTEMI (54.4 vs. 39.1\%) in comparison to males.

A number of sociodemographic, clinical, social and proximal factors have been associated with pre-hospital delay that includes the time required to recognise the presence of abnormal symptoms, attribute the symptoms to a condition requiring medical attention, to decide to seek care, arrange transportation, and travel to the hospital. ${ }^{18,19}$

Accordingly, admission within the first $2 \mathrm{~h}$ of symptom onset (42.5\%) was more common for males and urban location, while admission after $\geq 12 \mathrm{~h}$ of symptom onset was more common in females, rural location and NSTEMI diagnosis in our study population.

In relation identification of "waiting for symptoms to go away on its own" in almost half of our patients as the reason for the delay, patients who attributed symptoms to a heart attack rather than some other cause were reported to be more likely to have short decision times in the literature. $^{26}$

Therefore, besides the failure in attribution of symptoms to a heart attack by half of our patients, arrival of almost $60 \%$ of them to the hospital with the use of private cars rather than ambulance seems notable regarding the critical role of making initial contact with the EMS in promoting short pre-hospital delays. ${ }^{26}$ Hence, our findings seem to highlight the need for improved education of the general public on the

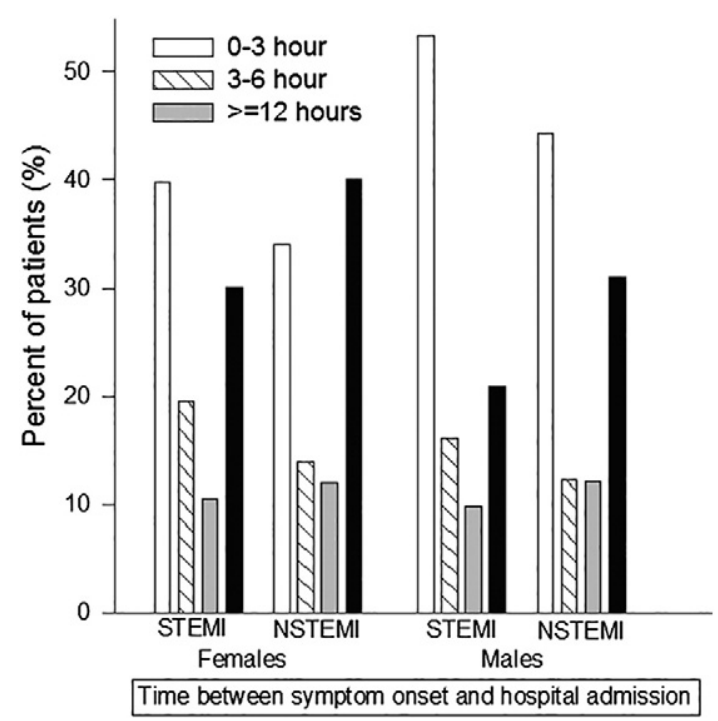

Fig. 2. Time between symptom onset and hospital admission in STEMI and NSTEMI patients with respect gender. 


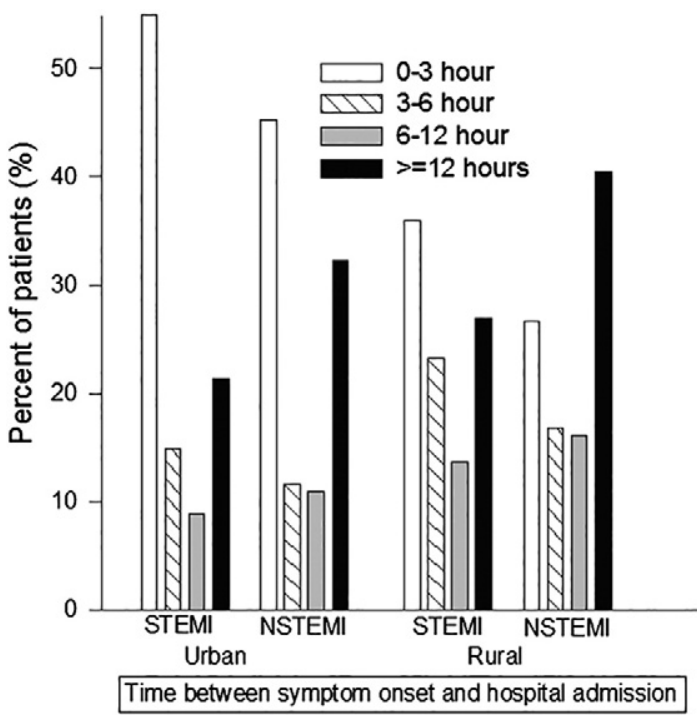

Fig. 3. Time between symptom onset and hospital admission in STEMI and NSTEMI patients with respect location of residence.

importance of seeking for medical attention early after the onset of acute ischemic symptoms.

Alike to short decision times for patients who had an STEMI rather than NSTEMI reported in the literature, ${ }^{18}$ our data showed that patients with STEMI, who are the most likely to benefit from coronary reperfusion strategies, presented to hospital earlier than patients with NSTEMI. Accordingly, our findings revealed that lytic treatment and primary PCI was possible in half of the patients admitting within the first $2 \mathrm{~h}$ of symptom onset while rescue $\mathrm{PCI}$ was the leading intervention in one third of patients admitting after $\geq 12 \mathrm{~h}$ of symptom onset. In this regard, delayed admission and contraindications were identified as the reasons for lower prescription rates for fibrinolytic treatment (23.0\%) in our study population when compared to ENACT ${ }^{20}$ and GRACE $^{21}$ studies.

Table 5

Hospitalization and mortality related findings with respect to diagnosis of STEMI or NSTEMI.

\begin{tabular}{|c|c|c|c|c|}
\hline \multirow[b]{2}{*}{ Hospitalization unit } & \multicolumn{2}{|c|}{ STEMI } & \multicolumn{2}{|c|}{ NSTEMI } \\
\hline & $\mathrm{N}$ & $\mathrm{n}(\%)$ & $\mathrm{N}$ & $\mathrm{n}(\%)$ \\
\hline Coronary ICU & 2057 & $\begin{array}{l}2018 \\
(98.1)\end{array}$ & 1537 & $\begin{array}{l}1388 \\
(90.3)\end{array}$ \\
\hline Regular ward & & $39(1.9)$ & & $149(9.7)$ \\
\hline Length of hospitalization (day) & & Mean (SD) & & Mean (SD) \\
\hline Coronary ICU & 1839 & $3.0(2.0)$ & 1206 & $2.8(2.0)^{*}$ \\
\hline Regular ward & 1313 & $3.0(2.0)$ & 968 & $3.1(2.3)$ \\
\hline Overall hospital stay & 1889 & $5.0(2.9)$ & 1390 & $4.6(2.9)^{* *}$ \\
\hline In-hospital mortality & \multicolumn{2}{|c|}{$\mathrm{n}(\%)$} & \multicolumn{2}{|c|}{$\mathrm{n}(\%)$} \\
\hline First $24 \mathrm{~h}$ & \multicolumn{2}{|c|}{$33(42.3)$} & \multicolumn{2}{|c|}{$6(20.7)^{*}$} \\
\hline After $24 \mathrm{~h}$ & \multicolumn{2}{|c|}{$45(57.7)$} & \multicolumn{2}{|c|}{$23(79.3)^{*}$} \\
\hline \multicolumn{5}{|l|}{ Reasons for mortality } \\
\hline $\begin{array}{l}\text { Sudden cardiac death/ventricular } \\
\text { fibrillation }\end{array}$ & \multicolumn{2}{|c|}{$20(22.7)$} & \multicolumn{2}{|c|}{$14(48.3)^{*}$} \\
\hline Pump failure & \multicolumn{2}{|c|}{$26(29.5)$} & \multicolumn{2}{|c|}{$6(20.7)$} \\
\hline Atrioventricular block & \multicolumn{2}{|c|}{$9(10.2)$} & \multicolumn{2}{|c|}{-} \\
\hline Cerebrovascular accident & \multicolumn{2}{|c|}{$5(5.7)$} & \multicolumn{2}{|l|}{ - } \\
\hline Other ${ }^{* *}$ & \multicolumn{2}{|c|}{$28(31.9)$} & \multicolumn{2}{|c|}{$9(31.0)$} \\
\hline \multicolumn{5}{|c|}{${ }^{*} \mathrm{p}<0.05$ and ${ }^{* *} \mathrm{p}<0.001$ compared to STEMI } \\
\hline${ }^{* *}$ Other reasons for death & \multicolumn{4}{|l|}{$\mathrm{n}$} \\
\hline Acute/chronic renal insufficiency & \multicolumn{4}{|l|}{4} \\
\hline Aspiration pneumonia & \multicolumn{4}{|l|}{3} \\
\hline Intracranial bleeding & \multicolumn{4}{|l|}{3} \\
\hline Papillary rupture/other ruptures & \multicolumn{4}{|l|}{2} \\
\hline Re-infarct & \multicolumn{4}{|l|}{8} \\
\hline CABG related complications & \multicolumn{4}{|l|}{8} \\
\hline Gastrointestinal bleeding & \multicolumn{4}{|l|}{4} \\
\hline Not recorded & \multicolumn{4}{|l|}{5} \\
\hline
\end{tabular}

Table 6

Creatinine kinase-myocardial band (CK-MB) and troponin I/T levels in consecutive measurements in the overall study population during their hospital stay.

\begin{tabular}{|c|c|c|c|c|}
\hline & $\mathrm{N}$ & Mean $( \pm S D)$ & $\mathrm{N}$ & Mean $( \pm S D)$ \\
\hline & \multicolumn{2}{|c|}{ CK-MB (IU/L) } & \multicolumn{2}{|c|}{ CK-MB (ng/L) } \\
\hline 1st measurement & 2085 & $65.0(114.9)$ & 1009 & 44.7 (137.2) \\
\hline 2nd measurement & 1749 & $136.2(557.7)^{* *}$ & 773 & $102.9(298.9)^{* *}$ \\
\hline \multirow[t]{2}{*}{ 3rd measurement } & 1235 & $95.8(369.8)^{* *},+$ & 454 & $78.9(176.4)^{*}$ \\
\hline & \multicolumn{2}{|c|}{ Troponin I (ng/mL) } & \multicolumn{2}{|c|}{ Troponin $\mathrm{T}(\mu \mathrm{g} / \mathrm{L})$} \\
\hline 1st measurement & 2636 & $8.5(27.6)$ & 143 & $7.0(31.7)$ \\
\hline 2nd measurement & 1976 & $22.6(60.0)^{* *}$ & 111 & $11.3(21.7)$ \\
\hline 3rd measurement & 1139 & $23.2(50.8)^{* *}$ & 69 & $9.4(23.4)^{*}$ \\
\hline
\end{tabular}

* $\mathrm{p}<0.05$; compared to first measurement.

** $\mathrm{p}<0.001$; compared to first measurement.

$+\mathrm{p}<0.05$; compared to second measurement.

Patients treated with early invasive management were more likely to be treated with medications and interventions recommended by the ACC/AHA guidelines and had a lower risk of inhospital mortality after adjusting for differences in clinical characteristics and after comparing propensity-matched pairs. ${ }^{22}$ Hence, pronounced use of ASA (93.6\%), ACE inhibitors (71.6\%) and statins (72.7\%) in our patients seem to be in line with the drug classes recommended in the Joint European Societies' guidelines for CVD prevention including aspirin or other platelet-modifying drugs in all patients except those who are aspirin intolerant, beta-blockers in those after MI, ACE inhibitors/angiotensin receptor blockers in those with impaired left ventricular function, lipidlowering drugs (statins) in all patients and anticoagulants in those at risk of systemic embolization. ${ }^{8,23}$

While PCI was performed more commonly than ENACT ${ }^{20}$ but comparably lesser than GRACE $^{24}$ studies, giving the fact that $13 \%$ of our patients have been transferred to other hospitals mainly for the need of invasive intervention (90.0\%). While no follow-up data were available for these patients, it is fair to assume that an additional $11 \%$ of TURKAKS study population to undergo $\mathrm{PCI}$.

Accordingly, our findings related to identification of left bundle branch block (LBBB) in $4.3 \%$ of patients with NSTEMI is in line with a past report indicating that a substantial proportion of patients diagnosed with NSTEMI had core LBBB or clinically significant ST-segment deviation on admission ECG that was not recognized in actual clinical practice. $^{25}$

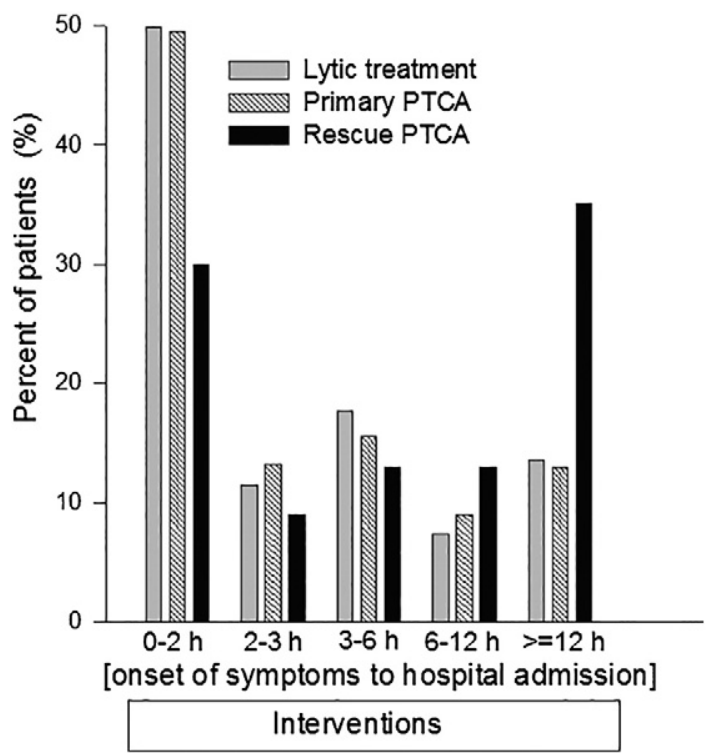

Fig. 4. Type of treatment (lytic drugs, primary or rescue percutaneous coronary intervention (PCI)) according to admission time after the onset of symptoms. 
Table 7

Type of treatment with respect to the diagnosis of STEMI or NSTEMI.

\begin{tabular}{|c|c|c|}
\hline & $\begin{array}{l}\text { STEMI } \\
(\mathrm{n}=2102)\end{array}$ & $\begin{array}{l}\text { NSTEMI } \\
(\mathrm{n}=1593)\end{array}$ \\
\hline Fibrinolytic treatment & $\mathrm{n}(\%)$ & \\
\hline Prior to admission & $65(3.1)$ & $4(0.3)$ \\
\hline In-hospital & $826(39.3)$ & $\begin{array}{l}19(1.2)^{\mathrm{a}}+36 \\
(2.3)^{\mathrm{b}}\end{array}$ \\
\hline Streptokinase & $362(44.5)$ & $6(37.5)$ \\
\hline Tissue plasminogen activator & $451(55.5)$ & $10(62.5)$ \\
\hline None & $559(26.6)$ & $753(47.2)$ \\
\hline Delayed admission & $121(21.7)$ & $368(48.9)$ \\
\hline Contraindication & $181(32.4)$ & $289(38.4)$ \\
\hline \multicolumn{3}{|l|}{ In-hospital interventions } \\
\hline \multicolumn{3}{|l|}{$\begin{array}{l}\text { Coronary angiography after fibrinolytic } \\
\text { therapy }\end{array}$} \\
\hline First $24 \mathrm{~h}$ & $130(33.6)$ & $11(18.6)$ \\
\hline Between 24 and $72 \mathrm{~h}$ & $115(29.7)$ & $14(23.7)$ \\
\hline After $72 \mathrm{~h}$ & $142(36.7)$ & $34(57.6)$ \\
\hline Total & $387(18.4)$ & $59(3.7)$ \\
\hline \multicolumn{3}{|l|}{ Coronary angiography-NSTEMI } \\
\hline First $24 \mathrm{~h}$ & $4(6.3)$ & $35(5.7)$ \\
\hline Between 24 and $72 \mathrm{~h}$ & $28(43.8)$ & $395(64.8)$ \\
\hline After $72 \mathrm{~h}$ & $32(50.0)$ & $180(29.5)$ \\
\hline Total & $64(3.0)$ & $610(38.3)$ \\
\hline \multicolumn{3}{|l|}{$\begin{array}{l}\text { Primary percutaneous transluminal } \\
\text { coronary angioplasty }\end{array}$} \\
\hline Within the first $3 \mathrm{~h}$ & $383(65.3)$ & $25(43.1)$ \\
\hline Between 3 and $6 \mathrm{~h}$ & $128(21.8)$ & $16(27.6)$ \\
\hline Between 6 and $12 \mathrm{~h}$ & $76(13.0)$ & $17(29.3)$ \\
\hline Total & $587(27.9)$ & $58(3.6)$ \\
\hline $\begin{array}{l}\text { Rescue percutaneous transluminal } \\
\text { coronary angioplasty }\end{array}$ & $92(4.4)$ & $10(0.6)$ \\
\hline PTCA in cardiogenic shock & $10(0.5)$ & $3(0.2)$ \\
\hline Coronary artery bypass graft surgery & $40(1.9)$ & $49(3.1)$ \\
\hline
\end{tabular}

a Before diagnosis.

b After diagnosis.

A complete LBBB in the setting of ischemic chest pain that is presumably new has been recommended to be managed as STEMI and considered also as an indication for thrombolytic therapy. ${ }^{33}$ Therefore identification of fibrinolytic treatment in $1.2 \%$ of patients diagnosed with NSTEMI in our study population may be associated with the administration of lytic treatment for this group of patients with LBBB or change of clinical picture from NSTEMI to STEMI in some patients. This underscores the urgent need for more accurate categorization of ACS according to current practice guidelines to maximize delivery of potentially life-saving reperfusion therapy to all eligible patients. ${ }^{25}$

Given the fact that high prevalence of low HDL-cholesterol levels specific to our country, ${ }^{16}$ our findings related to significant reduction in total cholesterol $(\mathrm{mg} / \mathrm{dL} ; \mathrm{p}<0.001)$ and LDL $(\mathrm{mg} / \mathrm{dL} ; \mathrm{p}<0.001)$ from admission to discharge in the overall population seem to indicate appropriate prescribing of cardioprotective medications through the study period in our population.

In this regard, reduction in prescription of stains from $57.0 \%$ at admission to $21.0 \%$ at discharge while increase in prescription of other lipid lowering drugs from $5.0 \%$ at admission to $33.0 \%$ at discharge in our study population seem reasonable considering significant improvement in cholesterol levels at discharge in our study as well as compatible with the achievement of recommended total and LDL cholesterol goals in $67.1 \%$ of patients included in the Turkey arm of EUROASPIRE III study. ${ }^{16}$

The biochemical identification of myocardial injury has long been used as a diagnostic aid in ACS patients with serum markers providing vital information regarding diagnosis and prognosis. ${ }^{26}$ In this regard, the significant reduction in CK-MB and troponin I/T levels during consecutive measurements in our study population with more predominant improvement in STEMI group than NSTEMI group seems to be in line with the statement that although the presence of troponin in a patient with NSTEMI has been considered as an indicator of increased risk of an adverse outcome suggesting the need for aggressive antithrombotic management, the same aggressive anti-thrombotic treatment should also be applied in the absence of a positive serum troponin with other high-risk features like ST-segment shift. ${ }^{27}$

Despite the fact that the incidence of NSTEMI is known to be high and it is the principal cause of admission among patients with ischemic heart disease, ${ }^{28}$ our results revealed the diagnosis of STEMI in $57.0 \%$ vs. NSTEMI in $43.0 \%$ of Turkish population composed of ACS patients. This seems to indicate the importance of continuing education of practicing physicians to the significance of troponin elevation and to the new AMI definition with a substantial influence on their triage practices, ${ }^{29}$ since the introduction of troponin, the new AMI definition and the revised NSTE ACS guidelines was reported to lead to the identification of a much larger population as high risk with a substantial increase in the overall number of patients admitted with NSTE. ${ }^{29}$

Of 107 cases (2.9\%) with in-hospital mortality in the overall population, STEMI was associated with mortalities within the first $24 \mathrm{~h}$ of admission and due to pump failure were more common among patients with STEMI whereas mortalities after $24 \mathrm{~h}$ of admission and due to sudden cardiac death/VF were more common in patients with NSTEMI. Accordingly, being higher for STEMI than NSTEMI patients, overall mortality rates were reported to be 3.7\% in Euro Heart Survey, ${ }^{30} 4.5 \%$ in the GRACE registry ${ }^{31}$ and $7.4 \%$ in the BLITZ survey. ${ }^{32}$ While the overall mortality rate in our population is lesser than these reports, it has to be kept in mind that since the outcome of the patients that were transferred to other hospitals was not available for TURKAKS, the death rate might possibly have been underrated.

TURKAKS Study provides the first large scale data on hospital management of acute coronary syndromes in Turkey based on real-life practice from a mixture of academic and non-academic institutions. It has generated valuable data on the reasons of delays in hospital admission of ACS patients and made us consider the need for increased awareness in the society. Moreover, it is reassuring that in general, the TURKAKS findings are consistent with other international data, wherever such data are available.

\section{Concluding remarks}

As a result, this national registry conducted as a first large scale attempt to describe the patient profile, presentation characteristics and the diagnostic and practice patterns in ACS in a representative sampling for Turkish population revealed predominancy of male gender (73.5\%), age of 51 to 70 years (55.4\%), urban location (76.6\%) and STEMI type of ACS (56.9\%). Besides, females were associated with older age, higher incidence of concomitant diseases and the increased likelihood of NSTEMI diagnosis compared to males. The delay between onset of symptoms and hospital admission was more prominent in rural locations, among females and in NSTEMI patients when compared to urban location, males and STEMI patients. Leading substantial amount of ACS patients to miss the critical period for the therapeutic interventions, hence the opportunity to prevent future disease related morbidity, the misattribution of the symptoms to a non-cardiac and potentially less serious cause and the neglect of the condition by the patient was remarkable.

In conclusion, though a multidisciplinary programme appropriately adapted to the medical, cultural and economic setting of our country to achieve a higher standard of preventive care for coronary patients through more effective lifestyle intervention; yet, control of risk factors, appropriate use of cardioprotective medication, furthermore educational and counseling interventions that encompasses both the public clinical staff health seem crucial for faster admission as well as the accurate diagnosis of ACS.

\section{Limitations of the study}

This study has been initiated during the last quarter of 2009 and completed in 2010. Despite various presentations at congresses at 
Hematological and biochemical findings in the overall population with respect to gender and the location of residence.

\begin{tabular}{|c|c|c|c|c|c|c|c|c|c|c|c|c|c|}
\hline \multirow{4}{*}{$\begin{array}{l}\text { Hematological findings } \\
\text { Hemoglobin }(\mathrm{g} / \mathrm{dL})\end{array}$} & \multirow{2}{*}{\multicolumn{3}{|c|}{ Overall }} & \multicolumn{5}{|c|}{ Gender } & \multicolumn{5}{|c|}{ Location of residence } \\
\hline & & & & \multicolumn{2}{|l|}{ Male } & \multicolumn{3}{|c|}{ Female } & \multicolumn{2}{|l|}{ Urban } & \multicolumn{3}{|c|}{ Rural } \\
\hline & $\mathrm{N}$ & Mean $( \pm S D)$ & $\mathrm{p}$ & $\mathrm{N}$ & Mean $( \pm S D)$ & $\mathrm{N}$ & Mean $( \pm S D)$ & $\mathrm{p}$ & $\mathrm{N}$ & Mean $( \pm S D)$ & $\mathrm{N}$ & Mean $( \pm S D)$ & $\mathrm{p}$ \\
\hline & & & & & & & & & & & & & \\
\hline Admission & 3426 & $13.8(1.9)$ & & 2527 & $14.3(1.7)$ & 899 & $12.6(1.7)$ & & 2604 & $13.8(1.9)$ & 798 & $13.8(2.0)$ & \\
\hline Discharge & 1278 & $13.1(1.9)$ & 0.000 & 953 & $13.5(1.8)$ & 325 & $11.9(1.5)$ & & 997 & $13.1(1.9)$ & 270 & $13.2(2.0)$ & \\
\hline \multicolumn{14}{|l|}{ Hematocrit (\%) } \\
\hline Admission & 3423 & $41.2(5.2)$ & & 2527 & $42.4(4.9)$ & 896 & $37.9(4.8)$ & & 2600 & $41.2(5.1)$ & 798 & $41.2(5.6)$ & \\
\hline Discharge & 1271 & $38.8(5.4)$ & 0.000 & 950 & $39.9(5.2)$ & 321 & $35.5(4.6)$ & & 993 & $38.7(5.3)$ & 267 & $39.1(5.7)$ & \\
\hline \multicolumn{14}{|l|}{ Thrombocyte $\left(10^{3} / \mathrm{mL}\right)$} \\
\hline Admission & 3386 & $254.5(80.3)$ & & 2499 & $248.2(76.9)$ & 887 & $272.0(86.7)$ & & 2575 & $255.1(78.7)$ & 790 & $252.5(85.4)$ & \\
\hline Discharge & 1269 & $249.1(81.9)$ & 0.000 & 947 & $243.4(79.3)$ & 322 & $265.8(87.1)$ & & 990 & $249.4(81.3)$ & 269 & $248.3(84.6)$ & \\
\hline Biochemical findings & $\mathrm{N}$ & Mean(SD) & $\mathrm{p}$ & $\mathrm{N}$ & Mean (SD) & $\mathrm{N}$ & Mean (SD) & $\mathrm{p}$ & $\mathrm{N}$ & $\operatorname{Mean}(\mathrm{SD})$ & $\mathrm{N}$ & $\operatorname{Mean}(S D)$ & $\mathrm{p}$ \\
\hline \multicolumn{14}{|l|}{$\mathrm{FBG}(\mathrm{mg} / \mathrm{dL})$} \\
\hline Admission & 3199 & $152.6(85.0)$ & & 2.338 & $145.4(78.3)$ & 861 & $171.9(98.5)$ & 0.000 & 2427 & $154.2(86.1)$ & 772 & $147.5(81.4)$ & 0.157 \\
\hline Discharge & 1206 & $122.5(50.2)$ & 0.000 & 877 & $119.5(47.8)$ & 329 & $130.6(55.5)$ & 0.048 & 940 & $123.3(51.0)$ & 266 & $119.7(47.3)$ & 0.312 \\
\hline \multicolumn{14}{|l|}{ HbA1c $(\%)$} \\
\hline Admission & 243 & $7.3(2.5)$ & & 162 & $7.1(2.5)$ & 81 & $7.8(2.4)$ & 0.693 & 201 & $7.4(2.5)$ & 42 & $7.1(2.4)$ & 0.947 \\
\hline Discharge & 114 & $6.7(2.0)$ & 0.050 & 83 & $6.4(1.9)$ & 31 & $7.5(2.0)$ & & 93 & $6.7(1.9)$ & 21 & $6.6(2.3)$ & \\
\hline \multicolumn{14}{|l|}{ Creatinine (mg/dL) } \\
\hline Admission & 3436 & $1.1(0.6)$ & & 2527 & $1.1(0.6)$ & 909 & $1.0(0.5)$ & 0.000 & 2628 & $1.1(0.6)$ & 808 & $1.0(0.5)$ & 0.457 \\
\hline Discharge & 1462 & $1.1(0.7)$ & 0.000 & 1069 & $1.2(0.7)$ & 393 & $1.0(0.5)$ & 0.900 & 1136 & $1.1(0.7)$ & 326 & $1.1(0.6)$ & 0.043 \\
\hline \multicolumn{14}{|l|}{ Total cholesterol (mg/dL) } \\
\hline Admission & 2439 & $191.9(48.0)$ & & 1796 & $187.9(45.8)$ & 643 & $203.1(52.2)$ & 0.000 & 1799 & $192.5(48.2)$ & 640 & $190.2(47.7)$ & 0.579 \\
\hline Discharge & 538 & $180.1(44.0)$ & 0.000 & 419 & $179.1(43.6)$ & 119 & $183.3(45.4)$ & 0.401 & 432 & $180.2(44.0)$ & 106 & $179.5(44.2)$ & 0.861 \\
\hline \multicolumn{14}{|l|}{ Triglyceride (mg/dL) } \\
\hline Admission & 2461 & $154.7(99.5)$ & & 1810 & $153.9(100.9)$ & 651 & $156.8(95.7)$ & 0.127 & 1821 & $157.7(102.0)$ & 640 & $146.2(91.8)$ & 0.090 \\
\hline Discharge & 531 & $153.4(85.9)$ & 0.535 & 413 & $156.2(88.6)$ & 118 & $143.2(75.6)$ & 0.502 & 428 & $151.1(79.3)$ & 103 & $162.9(109.1)$ & 0.987 \\
\hline \multicolumn{14}{|l|}{$\mathrm{LDL}(\mathrm{mg} / \mathrm{dL})$} \\
\hline Admission & 2566 & $124.4(47.6)$ & & 1902 & $122.3(44.8)$ & 664 & $130.3(54.5)$ & 0.022 & 1896 & $125.0(50.1)$ & 670 & 122.7 (39.7) & 0.159 \\
\hline Discharge & 535 & $113.6(43.4)$ & 0.000 & 416 & $114.1(45.0)$ & 119 & $111.9(37.6)$ & 0.309 & 431 & $114.6(45.6)$ & 104 & 109.6 (32.9) & 0.898 \\
\hline \multicolumn{14}{|l|}{$\mathrm{HDL}(\mathrm{mg} / \mathrm{dL})$} \\
\hline Admission & 2481 & $40.0(14.1)$ & & 1829 & 38.7 (13.9) & 652 & 43.5 (13.9) & 0.000 & 1833 & $39.9(14.1)$ & 648 & $40.2(14.2)$ & 0.808 \\
\hline Discharge & 517 & $39.1(14.5)$ & 0.000 & 402 & $37.9(12.8)$ & 115 & $43.0(18.7)$ & 0.284 & 418 & $39.2(15.2)$ & 99 & $38.7(10.7)$ & 0.879 \\
\hline
\end{tabular}

national level, a publication was not realized and this paper presents a cross-sectional data on the diagnosis and treatment for acute coronary syndrome for the years 2009-2010 for Turkey.

\section{Hematological and biochemical findings}

There was significant reduction in hemoglobin ( $\mathrm{g} / \mathrm{dL} ; \mathrm{p}<0.001)$, hematocrit (\%; $\mathrm{p}<0.001)$ and thrombocyte $\left(10^{3} / \mathrm{mL} ; \mathrm{p}<0.001\right)$ levels as well as FBG (mg/dL; p < 0.001), HbA1c (\%; p < 0.05), creatinine (mg/ $\mathrm{dL} ; \mathrm{p}<0.001)$, total cholesterol (mg/dL; $\mathrm{p}<0.001)$, LDL $(\mathrm{mg} / \mathrm{dL} ; \mathrm{p}<$ $0.001)$ and HDL $(\mathrm{mg} / \mathrm{dL} ; \mathrm{p}<0.001)$ from admission to discharge in the overall population. Most of the reductions were specific to female gender rather than males (Table 8).

\section{Acknowledgement}

The study is granted by IE Ulagay-Menarini Group, Turkey. We thank to Cagla Isman, MD and Prof. Sule Oktay, MD, PhD. from KAPPA Consultancy Training Research Ltd., Istanbul who provided editorial support and Dr. Oğuz Akbaș from Monitor CRO for statistical analysis.

TURKAKS Study Group: Abdulkadir KERPETEN MD KÜTAHYA, Abdullah DOĞAN MD ISPARTA, Abdullah ICÇLI MD KONYA, Abdulsamet GÜLSÜM MD BATMAN, Abdurrahman ASLAN MD İZMIR, Abdurrezzak BÖREKÇI MD ERZURUM, Abdusselam EMEK MD İZMIR, Abdüllatif ILBEY MD KONYA, Adife ÇETINTÜRK MD İZMİR, Adnan KAPAĞAN MD ESKIȘEHIR, Adnan PINAR MD İZMIR, Ahmet TEMIZZHAN MD ANKARA, Ahmet YILDIZ MD ISTANBUL, Ahmet BACAKSIZ MD KONYA, Ahmet KESER MD KONYA, Ahmet ORHAN MD ANTALYA, Ahmet SOYLU MD KONYA, Ahmet Arif YALÇIN MD ANKARA, Ahmet Muhammed SENTÜRK MD BURSA, Ahmet Oguz BAKTIR MD ANTALYA, Ahmet Ozan KINAY MD İZMIR, Alattın KALI MD ISPARTA, Ali AYDINLAR MD BURSA, Ali KARAGÖZ MD İSTANBUL, Ali YILDIZ MD SANLIURFA, Ali Fuat KARA MD
DIYARBAKIR, Ali Rıza AKYÜZ MD TRABZON, Ali Selim YALÇINKAYA MD ANTALYA, Alim HAYRAN MD KAYSERİ, Alparslan KÜÇÜK MD TOKAT, Alparslan KURTUL MD ANKARA, Alpay ARIBAŞ MD KONYA, Alper AYGEN MD İMIR, Alper KARAGÖZ MD GAZİANTEP, Alper SERÇELIK MD GAZIAANTEP, Anıl AVCI MD İSTANBUL, Arzu KARAÇELIK MD İSTANBUL, Asife ŞAHINARSLAN MD ANKARA, Aslan ÇELEBI MD İSTANBUL, Asuhan KARA MD MERSIN, Asuman BICCER YESSILAY MD ANKARA, Ataç ÇELIK MD TOKAT, Ayhan MUTLU MD KOCAELİ, Ayhan GÜRÇAĞAN MD EDİRNE, Aysun ERDEM MD KOCAELİ, Aytül BELGİ MD ANTALYA, Aziz KARABULUT MD DIYARBAKIR, Aziz KARADEDE MD DİYARBAKIR, Bahadır ŞARLI MD KAYSERİ, Bahar BOYDAK MD İZMIR, Barıș ÇELEBI MD MERSIN, Basri AMASYALI MD ANKARA, Baybars TÜREL MD BURSA, Behçet Kemal ENER MD ÇANAKKALE, Bernas ALTINTAS MD DİYARBAKIR, Birhan YILMAZ MD SIVAS, Birol ÖZKAN MD ISTANBUL, Burhan ÇABUK MD ZONGULDAK, Bülent AKÇA MD İZMİR, Bülent ÖZDEMIR MD BURSA, Bülent BOYACI MD ANKARA, Bülent İLÇÖL MD İSTANBUL, Bünyamin YAVUZ MD ANKARA, Cahıt AĞCAL MD ISPARTA, Cahide SOYDAŞ MD İZMIR, Celal KIRDAR MD ESKIŞEHIR, Celal KILIT MD YOZGAT, Cem NAZLI MD İZMIR, Ceyhun CEYHAN MD AYDIN, Cihanşah AKDOĞAN MD ESKISSEHIR, Cüneyt HAYRETDAĞ MD İZMİR, Cüneyt MÜDERRISOĞLU MD İSTANBUL, Cüneyt TÜRKOĞLU MD İZMİR, Çağın ÜREYEN MD ANKARA, Davran ÇICÇEK MD ANTALYA, Deniz ŞAHIN MD ANKARA, Deniz ŞELECI KURU MD GIRESUN, Dilek YEŞILBURSA MD BURSA, Diyar KÖPRÜLÜ MD SAMSUN, Dogan ERDOĞAN MD ISPARTA, Dursun Çayan AKKOYUN MD GAZIANTEP, Ebru YETKIN TÜRKKAN MD IZZMIR, Eda TOKUŞÇU MD ŞANLIURFA, Ednan BAYRAM MD ERZURUM, Ekrem KARAKAYA MD KAYSERİ, Ekrem GÜLER MD İSTANBUL, Embiya AKSAKAL MD ERZURUM, Emine GAZI MD EDİRNE, Emir DOĞAN MD ADAPAZARI, Emre ERKUŞ MD TRABZON, Emre KUŞ MD GAZIANTEP, Emrullah BASSER MD KAYSERİ, Engin BOZKURT MD ANKARA, Ercan TAŞTAN MD DIYARBAKIR, Ercan VAROL MD ISPARTA, Erdal DURU MD ANKARA, Erdal ESKİOĞLU MD ANKARA, Erdem DİKER MD ANKARA, 
Erdem ÖZEL MD İZMIR, Erden GÜLCÜ MD VAN, Erkan ÖZTEKIN MD İSTANBUL, Erol ASLAN MD MALATYA, Ersin IMMREN MD ANKARA, Ersin GÖZÜTOK MD ÇANAKKALE, Ertan URAL MD KOCAELİ, Evren DESTEGÜL MD YOZGAT, Eyyüp AYGÜL MD SAMSUN, Ezgi KALAYCIOĞLU MD ZONGULDAK, Ezgi Mert YAŞA MD MERSIN, Faruk AYAN MD ISTANBUL, Fatih KOÇ MD TOKAT, Fatih AKYAZICI MD BURSA, Fehmi KAÇMAZ MD BİNGÖL, Feray KOCA MD İZMİR, Fikret BESNILİ MD GAZIANTEP, Filiz ÖZERKAN MD İZMİR, Füsun İNCEER MD ÇORUM, Füsun ERDENEN MD İSTANBUL, Gökhan CINN MD MERSINN, Gül GÜRSOY MD ANKARA, Gülcan ABALI MD MERSIN, Güliz ERDEM YAZICI MD KIRIKKALE, Gülten SOP MD İZMIR, Hakan BAHADIR MD BURSA, Hakan DEMIR MD KOCAELİ, Hakan KÜLTÜRSAY MD İZMIR, Hakan ÖZKAN MD BURSA, Hakan AKILLI MD KONYA, Hakan ÇETIN MD ÇANAKKALE, Hakan GÜRÇINAR MD İZMİR, Hakan ÖNCEL MD ŞANLIURFA, Hakan SARI MD İSTANBUL, Haksun EBİNÇ MD KIRIKKALE, Halil HALIL MD İZMIR, Halil KAHRAMAN MD KONYA, Halim ÖNEY MD ESKIŞEHIR, Hamza DUYGU MD İZMIR, Harun KILIÇ MD ANKARA, Harun KOCA MD İSTANBUL, Hasan TURHAN MD MALATYA, Hasan Korkmaz MD ELAZIĞ, Hasan Ali GÜMRÜKÇÜOĞLU MD VAN, Hasan Murat UĞURLU MD DIYARBAKIR, Hatem ARI MD KONYA, Hazel BEŞIKTEPE MD İZMIR, Hürkan KURŞAKLIOĞLU MD ANKARA, Hüsamettin ATASEVER MD ADAPAZARI, Hüseyin BOZDEMIR MD İZMIR, Ilgın KARACA MD ELAZIĞ, Isık ERDOGAN MD İSTANBUL, İbrahim AKSOY MD GAZIANTEP, İbrahim DEDEOĞLU MD ŞANLIURFA, İbrahim SARI MD GAZIANTEP, İlksen ATASOY MD TOKAT, İlyas GÖKŞEN MD GAZİANTEP, İlyas KAYA MD DIYARBAKIR, İnan SOYDAN MD İZMİR, İsmail ATES MD ANTALYA, İstemihan TENGIZ MD İZMIR, Jülide UZUNONAT MD ÇORUM, Jülide YAĞMUR MD MALATYA, Kaan OKYAY MD ÇORUM, Kenan İLTÜMÜR MD DIYARBAKIR, Lale KOLDAŞ MD İSTANBUL, Leyla ASLAN MD İZMIR, M.Zihni BILIK MD DIYARBAKIR, M.Zülküf KARAHAN MD DİYARBAKIR, Mahir ÇífÇ̧I MD MARDIN, Mahmut AÇIKEL MD ERZURUM, Mahmut ŞAHIN MD SAMSUN, Makbule Kutlu KARADAĞ MD ELAZIĞ, Mecdi ERGÜNEY MD İSTANBUL, Mehdi ZOGHİ MD İZMIR, Mehmet BOSTAN MD RIZE, Mehmet AKSOY MD GAZIANTEP, Mehmet AYDIN MD İZMIR, Mehmet BOYUNSUZ MD GAZIANTEP, Mehmet DEMIR MD ISPARTA, Mehmet ERTÜRK MD İSTANBUL, Mehmet FIRAT MD MERSIN, Mehmet ÖZAYDIN MD ISPARTA, Mehmet SONBAHAR MD IZMIIR, Mehmet Erdinç ARIKAN MD İZMIR, Mehmet Ziya MOCAN MD İSTANBUL, Memet BALIN MD ELAZIĞ, Memet Vedat ÇALDIR MD K.MARAŞ, Meral KAYIKÇIOĞLU MD İZMİR, Mert ÖZBAKKALOĞLU MD İZMİR, Meryem AKTOZ MD EDIRNE, Metin GÜRBÜZ MD BURSA, Mikail YARLIOĞLUES MD KAYSERİ, Mohammad AMANCAN MD BURSA, Muhammed AKSOY MD ESKIŞEHIR, Murat AKÇAY MD ANKARA, Murat FAZLIOĞLU MD GIRESUN, Murat ÖZDAMAR MD İZMİR, Murat TULMAÇ MD KIRIKKALE, Murat SAKALLI MD KONYA, Murat SUCU MD GAZIANTEP, Murtaza ŞERIFI MD KOCAELİ, Mustafa AKIN MD İZMİR, Mustafa ERKUL MD ADAPAZARI, Mustafa ŞAN MD BURSA, Mustafa KAPLANGÖRAY MD DIYARBAKIR, Mustafa OYLUMLU MD GAZIANTEP, Mustafa ÖZGÜL MD VAN, Mustafa TUNCER MD VAN, Mustafa YURTDAS MD BATMAN, Mustafa Aydın DINÇER MD BALIKESİR, Mustafa Kemal EROL MD ERZURUM, Mutlu GÜNGÖR MD ANKARA, Mümin ETEMOĞLU MD İZMIR, Naci COŞKUN MD ELAZIĞ, Nazan BiTiR MD İSTANBUL, Nazan KANAL MD İSTANBUL, Nazmi GÜLTEKIN MD İSTANBUL, Necati DAĞLI MD ELAZIĞ, Nezire GÜLLÜ MD KONYA, Nihan KAHYA EREN MD İZMIR, Nihat AKÇAY MD SAMSUN, Nihat KALAYCI MD YOZGAT, Nihat ÖZER MD İSTANBUL, Nizamettin TOPRAK MD DIYARBAKIR, Nuri CÖMERT MD İSTANBUL, Nurtaç ÖZER MD KIRIKKALE, Oğuz YAVUZGIL MD İZMİR, Oğuzhan BARAN MD KAYSERİ, Oktay BILLGIR MD İZMİR, Onur AKPINAR MD GAZIAANTEP, Orhan DOĞRU MD BURSA, Orhan BERKER MD İSTANBUL, Orhan MADEN MD ANKARA, Orhan ÖZER MD GAZIANTEP, Osman MUTLU MD ESKISSEHİR, Osman MAVIŞ MD İSTANBUL, Osman Akın SERDAR MD BURSA, Osman Alper ONBAȘILI MD AYDIN, Ömer ALYAN MD DIYARBAKIR, Ömer Özkan DUMAN MD İZMIR, Ömür KURU MD GİRESUN, Önder ÖZTÜRK MD DIYARBAKIR, Öner ÖZDOĞAN MD İZMİR, Özcan ÖZDEMIR MD ANKARA, Özcan YILMAZ MD SAMSUN, Özgür Yaşar AKBAL MD KIRIKKALE, Özlem ÖZCAN MD ANKARA, Ramazan ÖZDEMIR MD MALATYA, Ramazan TOPSAKAL MD KAYSERİ, Recep DEMIRBAĞ MD
ŞANLIURFA, Refik BAYSAL MD MERSIN, Regaip ZEHIR MD İSTANBUL, Remzi YILMAZ MD ŞANLIURFA, Reşat AYALP MD ADANA, Rıdvan UÇAR MD GIRESUN, Rıdvan YALÇIN MD ANKARA, Rıza HAKIKİ MD ANKARA, S.Murat ASLAN MD ISPARTA, Sabahattin TOKTAŞ MD ADANA, Sabri GAZI MD EDIRNE, Sadık DURAN MD BALIKESIR, Sait ALAN MD DIYARBAKIR, Salman ÇELIK MD ÇANAKKALE, Savaş ÇELEBİ MD ANKARA, Sebahattin ATEŞAL MD İSTANBUL, Selim KUL MD TRABZON, Semir ÖZTOPRAK MD MARDIN, Serdar BIÇEROĞLU MD İZMIR, Serkan MENEKŞE MD İZMIR, Süleyman AYSEL MD VAN, Seref ULUCAN MD KONYA, Şerife AKSOY MD GAZIANTEP, Şükrü KARAASLAN MD KONYA, Şükrü ÜNAL MD NEVŞEHIR, Tahir DURMAZ MD ANKARA, Tarık YILDIRIM MD EDIRNE, Tarkan TEKTEN MD AYDIN, Taylan Erdem ŞAHIN MD AFYON, Tayyar GÖKDENIZ MD İSTANBUL, Telat KELEŞ MD ANKARA, Tezcan PEKER MD BURSA, Tolga ÖZYİĞITT MD İSTANBUL, Tunay ŞENTÜRK MD BURSA, Turan TURHAN MD TRABZON, Türkay ÖZCAN MD MERSIN, Uğur TAŞBAȘ MD BURSA, Ünal GÜNTEKIN MD VAN, Vedat KOCA MD BURSA, Veli KALA MD İZMIR, Yekta GÜRLERTOP MD ERZURUM, Yeşim HOŞCAN MD ANTALYA, Yıldız DOGAN MD ŞANLIURFA, Yılmaz YALÇINKAYA MD İZMİR, Yuksel DOGAN MD İSTANBUL, Yunus EMIROĞLU MD VAN, Yusuf YAKAR MD TOKAT, Yusuf TAVIL MD ANKARA, Zafer Nart BAYTUGAN MD KARS, Zehra GÜVEN ÇETIN MD ANKARA, Zerrin YíĞiT MD İSTANBUL, Zeynep ENGIN SAÇAR MD İSTANBUL, Ziya KURHAN MD İZMIR, Kürşat ASLAN MD İSTANBUL, Hasan Çetin AYDIN MD IZMIR, İlke AKYILDIZ MD IZMIR, Pelin PINAR MD MANISA, Halim SÖZCÜER MD İZMIR, Zafer ULUSAN MD İZMIR, Hikmet FEYIZOĞLU MD İSTANBUL, Hüseyin ARINÇ MD KAYSERİ, Savaş BEYAZTAȘ MD KAYSERİ, Selçuk DOĞAN MD KAYSERİ, Kenan MINARECI MD ANTALYA, Haluk YEĞiN MD ANTALYA, Serkan KAVAKLI MD ANTALYA, Ali BOYACI MD ISPARTA, Hakan TIKIZ MD MANISA, Nihat PEKEL MD IZMIR, Osman ERK MD İSTANBUL, Osman KARAKAYA MD İSTANBUL, Ömer YEĞINER MD İSTANBUL, Eralp ULUSOY MD İSTANBUL, Şenay BANK AKYILDIZ MD İSTANBUL, Serdar AKYÜZ MD ESKIŞEHİR, Çağatay ERTAN MD AFYON, Önder AKÇİ MD AFYON, Muhammed TAHTA MD AFYON, Zeydin ACAR MD TRABZON, Muhittin GÜNDOĞDU MD SAMSUN, Beyhan ERYONUCU MD ANKARA, Şengül ÇEHRELİ MD ANKARA, Ömer AKYÜREK MD AFYON, Yüksel AKSOY MD ANKARA, Ersel ONRAT MD AFYON, Merih AKBAŞ MD KOCAELİ, Selçuk BAŞÇIL MD KOCAELİ, Murat ERSANLI MD İSTANBUL, Dursun ARAS MD ANKARA, Mustafa ÖZKAN MD ANKARA, Cemal SAĞLAM MD ANKARA, Atilla İYISOY MD ANKARA, Ömer GÖKTEKIN MD ESKIŞEHIR, Emine RIZAOĞLU MD İSTANBUL, Ali DENIZ MD BARTIN, Erol SAĞATLİ MD ZONGULDAK, İzzet TANDOĞAN MD SİVAS, Okan Onur TURGUT MD SIVAS, Can YONTAR MD SIVAS, Güllü MERT AMIOĞLU MD SIVAS, Alim ERDEM MD SIVAS, Zehra ERKAL MD ANTALYA, Özkan DEDE MD ANTALYA, Atilla KESKIN MD MANISA, Seyhan ÇETIN MD BALIKESIR, Selçuk YAZICI MD BALIKESİR, Erkan EKİCIBBAŞI MD İSTANBUL, Sinan DAĞDELEN MD İSTANBUL, Eren GÜRSOY MD ANKARA, Abdurrahman KALE MD ORDU, İSTANBU, Fevzi ALO MD İSTANBUL, Alpaslan BİRDANE MD ESKIŞEHİR, Erol ÜNLÜER MD İZMiR.

\section{References}

1. The GRACE Investigators. Rationale and design of the GRACE (Global Registry of Acute Coronary Events) project: a multinational registry of patients hospitalized with acute coronary syndromes. Am Heart J 2001;141:190-199.

2. D'Ascenzo F, Biondi-Zoccai G, Moretti C, et al. TIMI, GRACE and alternative risk scores in Acute Coronary Syndromes: a meta-analysis of 40 derivation studies on 216,552 patients and of 42 validation studies on 31,625 patients. Contemp Clin Trials 2012 Jan;11 [Epub ahead of print], https://doi.org/10.1016/j.cct.2012.01.001.

3. Burzotta F, De Vita M, Gu YL, et al. Clinical impact of thrombectomy in acute ST-elevation myocardial infarction: an individual patient-data pooled analysis of 11 trials. Eur Heart J 2009;30:2193-2203.

4. Antman FM, Hand M, Armstrong PW, et al. 2007 Focused Update of the ACC/AHA 2004 Guidelines for the Management of Patients With ST-Elevation Myocardial Infarction: a report of the American College of Cardiology/American Heart Association Task Force on Practice Guidelines: developed in collaboration With the Canadian Cardiovascular Society endorsed by the American Academy of Family Physicians: 2007 Writing Group to Review New Evidence and Update the ACC/AHA 2004 Guidelines for the Management of Patients With ST-Elevation Myocardial Infarction, Writing on Behalf of the 2004 Writing Committee. Circulation 2008;117:296-329. 
5. Granger CB, Steg PG, Peterson E, et al. Medication performance measures and mortality following acute coronary syndromes. Am J Med 2005;118:858-865.

6. EUROASPIRE Study Group. EUROASPIRE. A European Society of Cardiology survey of secondary prevention of coronary heart disease: principal results. Eur Heart J 1997:18:1569-1582.

7. EUROASPIRE Study Group. Lifestyle and risk factor management and use of drug therapies in coronary patients from 15 countries. Principal results from EUROASPIRE II. Euro Heart Survey Programme. Eur Heart J 2001;22:554-572.

8. Kotseva K, Wood D, De Backer G, et al. EUROASPIRE III: a survey on the lifestyle, risk factors and use of cardioprotective drug therapies in coronary patients from 22 European countries. Eur J Cardiovasc Prev Rehabil 2009;16:121-137.

9. EUROASPIRE Study Group. Clinical reality of coronary prevention guidelines: a comparison of EUROASPIRE I and II in nine countries. Lancet 2001;357:995-1001.

10. Onat A. Risk factors and cardiovascular disease in Turkey. Atherosclerosis 2001;156: $1-10$.

11. Onat A, Keleş İ, Çetinkaya A, et al. Prevalence of all-cause and coronary mortality in Turkish adults as assessed by 10-year follow-up data of the Turkish adult risk factor study (Article in Turkish). Türk Kardiyol Dern Ars 2001;29:8-19.

12. Mahley RW, Palaoğlu KE, Atak Z, et al. Turkish Heart Study: lipids, lipoproteins, and apolipoproteins. J Lipid Res 1995;36:839-859.

13. Satman I, Yılmaz T, Şengül A, et al. Population-based study of diabetes and risk characteristics in Turkey: results of the Turkish Diabetes Epidemiology Study (TURDEP). Diabetes Care 2002;25:1551-1556.

14. Altun B, Arıcı M, Nergizoğlu G, et al. Prevalence, awareness, treatment and control of hypertension in Turkey (the PatenT study) in 2003. J Hypertens 2005;23:1817-1823.

15. Abacı A, Oğuz A, Kozan O, et al. Treatment and control of hypertension in Turkish population: a survey on high blood pressure in primary care (the TURKSAHA study). J Hum Hypertens 2006;20:355-361.

16. Tokgözoğlu L, Kaya EB, Erol C. EUROASPIRE III: a comparison between Turkey and Europe. Turk Kardiyol Dern Ars 2010;38:164-172 [Article in Turkish].

17. Fox KAA, Goodman SG, Anderson Jr FA, et al. From guidelines to clinical practice: the impact of hospital and geographical characteristics on temporal trends in the management of acute coronary syndromes. The global registry of acute coronary events (GRACE). Eur Heart J 2003;24:1414-1424.

18. Perkins-Porras L, Whitehead DL, Strike PC, et al. Pre-hospital delay in patients with acute coronary syndrome: factors associated with patient decision time and home-to-hospital delay. Eur J Cardiovasc Nurs 2009;8:26-33.

19. Ottesen MM, Dixen U, Torp-Pedersen C, et al. Prehospital delay in acute coronary syndrome-an analysis of the components of delay. Int I Cardiol 2004:96:97-103.

20. Fox KA, Cokkinos DV, Deckers J, et al. The ENACT study: a pan-European survey of acute coronary syndromes. Eur Heart J 2000;21:1440-1449.

21. Fox KA, Eagle KA, Gore JM, et al. The Global Registry of Acute Coronary Events, 1999 to 2009-GRACE. Heart 2010;96:1095-1101.

22. Widimsky P, Zelizko M, Jansky P, et al. The incidence, treatment strategies and outcomes of acute coronary syndromes in the "reperfusion network" of different hospital types in the Czech Republic: results of the Czech evaluation of acute coronary syndromes in hospitalized patients (CZECH) registry. Int J Cardiol. 2007: $119-212-9$

23. Graham I, Atar D, Borch-Johnsen K, et al. European Guidelines on Cardiovascular Disease Prevention in Clinical Practice: Fourth Joint Task Force of the European Society of Cardiology and Other Societies on Cardiovascular Disease Prevention in Clinical Prevention in Clinical Practice (Constituted by representatives of nine societies and by invited experts). Eur J Cardiovasc Prev Rehabil 2007;14(suppl 2):S1-S113 [Executive summary: Eur J Cardiovasc Prev Rehabil 2007; 14 (Suppl 2): E1-E40; Eur Heart J 2007; 28:2375-2414].

24. Devlin G, Anderson FA, Heald S, et al. Management and outcomes of lower risk patients presenting with acute coronary syndromes in a multinational observational registry. Heart 2005;91:1394-1399.

25. Yan RT, Yan AT, Allegrone J, et al. Differences between local hospital and core laboratory interpretation of the admission electrocardiogram in patients with acute coronary syndromes and their relation to outcome. Am J Cardiol 2007;100:169-174.

26. Braunwald E, Antman EM, Beasley JW, et al. ACC/AHA guidelines for the management of patients with unstable angina and non-ST-segment elevation myocardial infarction: a report of the American College of Cardiology/American Heart Association Task Force on Practice Guidelines (Committee on the Management of Patients with Unstable Angina). J Am Coll Cardiol 2000;36:970-1062.

27. Fitchett D, Goodman S, Langer A. New advances in the management of acute coronary syndromes: matching treatment to risk. CMAJ 2001;164:1309-1316.

28. Bosch X, Verbal F, López de Sá E, et al. Differences in the management and prognosis of patients with non-ST segment elevation acute coronary syndrome according to the department of initial admission. Rev Esp Cardiol 2004;57:283-290 [Article in Spanish].

29. Zahger D, Hod H, Gottlieb S, et al. Influence of the new definition of acute myocardial infarction on coronary care unit admission, discharge diagnosis, management and outcome in patients with non-ST elevation acute coronary syndromes: a national survey. Int J Cardiol 2006;106:164-169.

30. Hasdai D, Behar S, Wallentin L, et al. A prospective survey of the characteristics, treatments and outcomes of patients with acute coronary syndromes in Europe and the Mediterranean basin-the Euro Heart Survey of Acute Coronary Syndromes. Eur Heart J 2002;23:1190-1201.

31. Fox KA, et al. Management of acute coronary syndromes. Variation in practice and outcome findings from the Global Registry of Acute Coronary Events (GRACE). Eur Heart J 2002;23:1177-1189.

32. DiChiara A, Chiarella F, Savonitto S, et al. Epidemiology of acute myocardial infarction in the Italian CCU network-the BLITZ study. Eur Heart J 2003;24:1616-1629.

33. Armstrong PW. New advances in the management of acute coronary syndromes: 2 Fibrinolytic therapy for acute ST-segment elevation myocardial infarction. CMAJ 2001;165:791-797 [Review]. 